\title{
Finnish Tax News
}

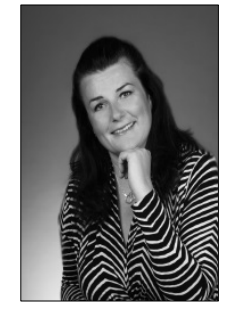

Doctor of Laws, Senior Tax Manager Kristiina Äimä

Faculty of Law of the University of Helsinki and KMPG Finland

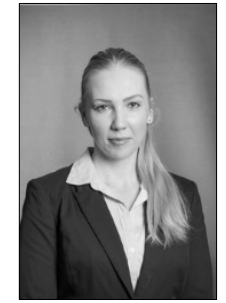

Master of Economics, Senior Tax Adviser Suvi Lamminsivu KPMG Finland

Finland received a new majority coalition government in June 2014. The new Government is formed between the National Coalition Party, the Social Democratic Party, the Swedish People's Party in Finland, the Green League and the Christian Democratic Party. The Government introduced some tax measures.

The Supreme Administrative Court has issued a number of interesting rulings in 2014. The most important ruling KHO 2014:119 deals with transfer pricing adjustments and hybrid loans.

\section{The Government Program}

On 24 June 2014, the President of the Republic appointed Finland's 73rd government. The goal of Prime Minister Alexander Stubb's Government is an open, fair and confident Finland.

The Government Program is based on the previous government's program as well as the structural policy program and policies relating to its implementation and to fiscal adjustment. The Government's priorities are reducing poverty, inequality and social exclusion, consolidating public finances and promoting sustainable economic growth, employment and competitiveness.

\section{Tax measures}

The Government Program includes some tax related measures. The Government will not introduce a windfall profit tax on electricity production but is looking into the possibility to introduce an envi- 
ronmental tax or a special based on the consumption of energy products ${ }^{1}$.

Entertainment expenses ${ }^{2}$ have been up to $50 \%$ tax-deductible in corporate income taxation until the end of 2013. The previous government reduced corporate income tax rate from $24.5 \%$ to $20 \%$. The tax rate reduction was partly financed by enacting entertainment expenses are fully nondeductible as of January 2014.

It turned out early this year that abolishment of deductibility of entertainment expenses has an adverse impact on the sales of Finnish hotel and restaurant branch. The new Government decided to reintroduce the deductibility of $50 \%$ of entertainment cost with effect from 1 January 2015. Reintroduction of the partial deductibility of entertainment cost is good news for the economy. Finnish tax policy may however be subject to criticism due to its inconsistency, unpredictability and short term approach.

Some amendments were introduced to taxation of individuals. The three lowest income tax brackets will be inflation adjusted in 2015. No adjustment will be made in 2016. Special tax reliefs will be introduced for families with children.

\section{Action plan against international tax avoidance}

The Government announced its action plan against international tax avoidance on 8 May 2014. The action plan aims at putting together key measures which can be used to combat international tax avoidance and tax evasion. The action plan also includes measures in order to control tax havens.

The measures are divided into five focus areas: 1) protection of tax base and harmful tax competition, 2) tax monitoring and exchange of taxation information, 3) tax transparency, 4) public procurement, and 5) tax matters in the field of development aid. All focus areas include Finland's goals and measures.

There are global, EU, Nordic and domestic level measures. Finland acts actively within the EU and also at the global forums to combat international tax avoidance and to increase transparency.

1 This note has been prepared partly on the basis of reports concerning Finland by Laura Ambagtsheer-Pakarinen at IBFD's Tax News Service, www.ibfd. org.

2 Entertainment expenses are linked to customers, business acquaintances or other people who have an impact on a firm's business activities. Entertainment expenses are paid in order to get new clients or to keep old clients or to otherwise promote one's business activities. Usually entertainment expenses consist of restaurant bills, gifts or accommodation and travel expenses.

\section{Kristiina Äimä E Suvi Lamminsivu}




\section{VAT on broadcasting, telecommunications and e- services}

On 27 June 2014, the bill ${ }^{3}$ transposing Council Directive 2008/8/EC amending the EU VAT Directive was enacted. The bill requires that telecommunications, broadcasting and electronic services will be taxed where the customer is established. In order to ensure the correct taxation, EU and non-EU businesses will need to determine the status of their customer (a taxable or a non-taxable person) and the place (in which country of the EU or outside the EU) where that customer belongs ${ }^{4}$.

\section{Act on Excise Duty on Electricity and Certain Fuels}

An Act (1072/2013) amending the Act on Excise Duty on Electricity and Certain Fuels (1260/1996) took effect on 1 April 2014. The new Act means that electricity consumption not only in industry, mining and agriculture, but also in data centres will attract a reduced, category II electricity tax rate.

In order to qualify for the reduced rate the data centre must be the operator's main business. Furthermore the data centre must have a minimum total power output of $5 \mathrm{MW}$. Depending on the rate of expansion in data centre operations, the legislative amendment translates into an electricity tax subsidy of some 10 million euros to data centres over the first years of the validity of the subsidy.

\section{Case law of the Supreme Administrative Court}

\subsection{KHO 2014:119}

On 3 July 2014, the Finnish Supreme Administrative Court (»the SAC'), issued its decision on a case concerning a hybrid loan from a Luxembourg company to a Finnish related company. The Finnish limited liability company was mainly owned by a Luxembourg company. In 2009 the Finnish company had received a loan of 15 MEUR from the Luxembourg company to alleviate the financial difficulties, and wanted to deduct EUR 1,337,500 as interest expenses paid to Luxembourg company. The loan did not have any provisions for repayment by a definite date and was under IFRS accounting rules treated as eq-

3 Regeringens proposition 56/2014.

4 European Commission: Explanatory Notes to prepare businesses for the new VAT rules for telecom, broadcasting and electronic services 
uity (hybrid loan). The loan was secondary in ranking of claims in comparison with bank loans. Based on Section 31 of the Finnish Tax Assessment Procedure Act the Finnish tax authorities recharacterized the loan as equity investment and consequently, disallowed the interest deduction.

Contrary to the view of the tax authorities, the SAC upheld the decision by the District Administrative Court of Helsinki. The SAC stated that the legal form of the loan cannot be disregarded and the hybrid loan cannot be recharacterized as equity investment pursuant to Section 31 of the Finnish Tax Assessment Procedure Act as this Section did not contain such a rule. Thus, the interest paid on the loan was deductible in the taxation of the Finnish subsidiary. Further, the SAC confirmed that the interpretation of Article 9 of the tax treaty may not overrule domestic tax regulations. This means that the OECD transfer pricing guidelines may not be applied in recharacterization without specific support from domestic tax law. The decision addresses the importance of the principle of legality in taxation.

\subsection{KHO 2014:66}

The SAC issued on 2 May 2014 its ruling KHO 2014:66 in which benefits received by the top management through a holding company structure were considered as earned income under the general Finnish anti-avoidance rule. The ruling reversed the advance ruling issued by the Finnish Central Tax Board.

The case involved an arrangement in which the top management of a public limited company had set up a holding company that purchased shares of the Plc. The acquisition of the shares of the Plc was financed with equity capital contributed by the top management and a loan granted by the Plc. The holding company had no other operations than owning the shares of the Plc on behalf of its shareholders. A shareholders' agreement had been concluded between the top management and the Plc concerning the possibility of merging the holding company with the Plc in accordance with the Finnish Limited Liability Companies Act. The shareholders' agreement also contained other terms concerning winding up the arrangement.

The SAC examined the arrangement as a whole taking into account the Finnish anti-avoidance rule. Based on this evaluation, the SAC took the view that the primary intention of the arrangements was that the top management potentially obtains the Plc's shares at a lower price than the fair market value. According to the SAC, business reasons for the management incentive scheme were relatively weak. Thus, the SAC ruled the income received from the arrangement by the shareholder of the holding company may with certain limitations be 
considered as earned income received from the employment relationship for tax purposes.

\subsection{KHO 2014:88}

The SAC issued on 30 May 2014 its ruling KHO 2014:88 concerning deductibility of costs incurred from MBA studies. In the case Doctor of Political Science, A, had completed the Executive MBA studies in foreign educational institution during the period between September 2008 and August 2010. In 2008 the total incurred costs for this education were in total EUR 42,556. These costs were not considered to be deductible for tax purposes. In fiscal year $2008 \mathrm{~A}$ had worked as a corporate executive. In addition, A had during the period between October 2009 and March 2010 completed Executive Leadership training in another foreign educational institution.

The SAC stated that the costs incurred from basic and further education as well as other occupational education are not considered to be income generating or retaining costs, which are deductible for tax purposes, but non-deductible living costs. The SAC ruled that Executive MBA training shall be considered as A's commercial further education or additional training related to the further education, which has improved the A's position in the labor market. Thus, these types of training expenditures are not tax-deductible for employees.

\subsection{KHO 2014:92}

On 4 June 2014 the SAC issued its ruling KHO 2014:92 concerning a relief on a transfer to the next generation. The SAC ruled that Section 55 of the Finnish Inheritance and Gift Tax Act shall be applied in a situation where the company's Finance Manager A, who was responsible for the external accounting of the family-owned company and its development, as well as human resources and payroll administration and who also was a member of the company's management team, will continue to carry on the family business with the asset which he had received as a gift, although he would no longer be a member of the company's board of directors.

\subsection{KHO 2014:67}

On 5 May 2014 the SAC issued its ruling KHO 2014:67 concerning an incorporation of a state-owned enterprise owned by a group of municipalities. The group of municipalities had through the state-owned enterprise carried on sales of research and laboratory services related to VAT exempt health and medical care. The group of municipalities had transferred the business through an asset deal to the established limited liability company in exchange of the total purchase price. Assets subject to a VAT deductible use in the group of municipalities 
had been transferred to the limited liability company. A part of the total purchase price had been allocated to these assets and the rest to the goodwill. The goodwill referred to customer relationships as well as such kind of know-how and human capital which was transferred with the staff. The limited liability company continued the activities which had earlier been in VAT exempt use in the state-owned enterprise of the group of municipalities.

The SAC ruled that the limited liability company did not use the assets and services in way which is subject to VAT. Therefore, Section 19 a of the Finnish Value Added Tax could not be applied. The transfer of goodwill was considered as service, and thus the provisions concerning VAT deductible health and medical care services were not applied. The SAC concluded that as there were not any exemptions, the group of municipalities was, to the extent the taxpayer had not been challenged, liable to VAT on the assets as well as the transfer of goodwill. 